\title{
Eastern Africa: a New Oil and Gas Frontier
}

\section{Benjamin Augé and Rose Nakayi}

\section{(2) OpenEdition}

\section{Journals}

Electronic version

URL: https://journals.openedition.org/eastafrica/377

DOI: 10.4000/eastafrica.377

ISSN: 2790-1076

\section{Publisher}

IFRA - Institut Français de Recherche en Afrique

\section{Printed version}

Date of publication: 1 April 2014

Number of pages: 1-16

ISSN: 2071-7245

\section{Electronic reference}

Benjamin Augé and Rose Nakayi, "Eastern Africa: a New Oil and Gas Frontier", Les Cahiers d'Afrique de I'Est / The East African Review [Online], 48 | 2014, Online since 07 May 2019, connection on 09 December 2021. URL: http://journals.openedition.org/eastafrica/377 ; DOI: https://doi.org/10.4000/ eastafrica.377 


\title{
Eastern Africa: a New Oil and Gas Frontier
}

\author{
Benjamin Augé \& Rose Nakayi
}

\section{Introduction}

The oil and gas industry in Eastern Africa is quite a new sector compared to the Gulf of Guinea where oil was produced from the end of the 1950s onwards. Though some exploration took place earlier on, with companies such a Shell, involved in Kenya in the 60 s or in Uganda in the $80 \mathrm{~s}^{1}$, a new frontier opened up during the last 10 years. Previously, companies were not making much effort to find the precious hydrocarbons in the region. The main reason for this lack of perseverance was that oil, "easy" to get and refine, was flowing elsewhere at that time.

So what has "unlocked" Eastern Africa? During the last decade, oil consumption has drastically risen worldwide. Today, the world's economy needs 88 million barrels per day (bpd) whereas, in 2001, the level was at 77 million. China and other Asian economies are driving the market up by increased demand. Until 1993, China was relying almost entirely on its internal oil and coal production; it is now buying more than 5 million bpd from the international market. This recent increase of daily oil consumption led petroleum firms to look for new reserves. Eastern Africa finally came into their radar and heavy exploration began in 2006 with the activities of two minnows, Tullow Oil and Heritage Oil, drilling wells around Lake Albert in Uganda. In the past, the two concerns have known success after success and added to the market billions of barrels of new oil. Once more they have opened up a new hydrocarbons province which has led dozens of oil firms to consider East Africa has a potentially huge and untapped reservoir.

Writing about oil and gas in the region is important especially at a time when publications and academic work are still scarce ${ }^{2}$. This paper reviews the oil exploration phase and the actual discoveries made in Eastern Africa and offers a prospective analysis of the oil sector for the coming years. It tackles specific challenges relative to the management of this resource in the region, such as landlocked reserves, border issues and governance. Though its main focus is Uganda/DRC and Kenya, the case of oil producing South Sudan, with the regional implications of its Independence, and prospects in Somalia, Ethiopia and

1 Kashambuzi, R. The Story of Petroleum Exploration in Uganda (1984-2008), Kampala, Impro Publications Ltd, 2010. 2 International Crisis Group (ICG), Black Gold in the Congo: Threat to Stability or Development Opportunity? July 2012. Global Witness, Uganda's Petroleum Legislation. Safeguarding the Sector, March 2012. Kashambuzi, The Story of Petroleum..., op.cit. 
Rwanda are drawn into the wider picture. In addition, new questions arise from the huge offshore gas reserves in Tanzania and Mozambique. Eastern Africa is understood as part of "Median Africa", reuniting the Great Lakes Region and Eastern Africa'. A number of these countries are (or have been in the recent past) characterized by armed conflict, State collapse and very poor governance ${ }^{4}$. Oil discoveries have the potential to widen the ridge between the once warring parties, as they fight about control of oil territories. Armed conflict has the potential to inhibit oil exploitation and governance. However, in some instances, oil discovery and exploitation could present renewed opportunities for peace through the expansion of economic ties and political cooperation.

In this paper, we start by offering a regional perspective on exploration and production in Eastern Africa. Then we shall review geopolitical issues such as borders, market and transportation. Finally, the topic of oil governance will be tackled paying special attention to the case of Uganda.

\section{Oil and gas: a regional perspective}

\section{The starting point: Lake Albert in Uganda and DRC}

With dozens of wells drilled since 2006, the three oil blocks around the Lake Albert in Uganda have already pushed this country to the rank of a major future oil province. 3.5 billion barrels will be put in production in the next five years by a consortium composed of Tullow (the first company to have taken the risk with Heritage) in the center of the Lake Albert region, the French behemoth Total, in the North, and one of the three state Chinese firms CNOOC, in the South. These three companies now have the capacity (both financial and technical) to exploit the oil for exportation and local transformation with a refinery. Yet the oil firms have rescheduled the beginning of regular production several times mostly because of technical and political problems, production is now due to start around 2018. More specifically, one of the main areas of negotiation between the executive and the oil companies has focused on extraction rates and whether or not to build a refinery locally. President Museveni defends a regional market perspective whereas the oil companies follow the global market trends which would lead to the depletion of oil reserves within a period of 10-15 years and exportation of crude through a pipeline. To date no Memorandum of Understanding has been signed, yet an agreement is under way for the construction of a 30 to 60000 bpd refinery out of the prospective of $180000 \mathrm{bpd}^{\text {production }}{ }^{5}$. However, some flow tests will begin in 2014 to supply power plants like Namanve (50 MW) and Electromaxx ${ }^{6}$ (20 MW) which were revamped to conform to the use of this new type of crude. The entire process of oil exploration in Uganda is handled by the Ministry for Energy and Minerals in

\footnotetext{
3 Lacoste, Y. «Introduction », Hérodote (special issue) ‘Géopolitique d'une Afrique médiane', nº 86-87, 1997.

4 Generally see Collier, P. War Guns and Votes. Democracy in Dangerous Places, Harper Collin Publishers, 2009.

5 The East African, 20-26 April 2013, p. 6. Daily Monitor, 16 April 2013, p. 1, 3.

6 Africa Energy Intelligence, nº56, 20 July 2011.
} 
Kampala with a special unit based in Entebbe: the Petroleum Exploration and Production Department (PEPD).The Department is planning to allocate 14 new blocks in 2013 as soon as President Yoweri Museveni enforces the oil laws that were passed in parliament in 2012. More than 40 companies have formally made an application to the Ministry of Energy for these blocks such as the Russian private firm Lukoil, the Italian ENI and the Indian Essar? ${ }^{7}$.

On the other side of Lake Albert, in the Democratic Republic of Congo ${ }^{8}$, exploration is very slow. Three Producing Sharing Agreements (PSA) were signed in the same zone by three different Congolese governments between 2006 and 2010. The last contract -the one signed by the President Joseph Kabila- was given to two unknown companies: Caprikat and Foxwhelp. Created a couple of months before getting the exploration blocks in June 2010, the companies are owned by a mix of South African shareholders ${ }^{9}$ and of businessmen close to Kabila's power, such as its itinerant ambassador Antoine Ghonda ${ }^{10}$. Without the necessary funds or the technical know-how to explore those landlocked areas, Caprikat and Foxwhelp have just shot a quick 2D seismic study and are hoping to make a profit when bought by bigger companies. The regime is just trying to make some money out of the contracts. In spite of prospective oil resources, the Congolese side of the lake might remain unexplored for a long time unless Kinshasa expropriates the two firms. Total, Tullow and CNOOC who are keen on controlling both shores of the lake refuse to deal with Caprikat and Foxwhelp directly; the two firms are considered as "radioactive" and too "political" for well established firms with boards of directors, shareholders and, for two out of three, listed.

South of Lake Albert, prospective exploration is taking place. Total is controlling block 3 and will conduct 2D seismic, during 2013; then based on results, it might drill in 2014/2015. Further south, around Lake Edward, the British minnow Soco has taken over the very challenging area of the Virunga Park, for security and environmental reasons. There is still a long way to go before understanding the real potential of the zone, since the drilling phase might not take place before years.

Apart from security issues with rebellion movements and a disorganized Congolese army, the Ministère des hydrocarbures in Kinshasa, generally bypassed by close aides of President Joseph Kabila, takes a long time to clear oil firms. This has led concerned parties in DRC to believe that the regime does not want oil to be produced in Ituri and the two Kivus. Even more so since the government in the Congo has not tightened its grip over these areas. The paralysis in Congo is in sharp contrast with the urge to produce oil found in Uganda. Yoweri Museveni wants the oil to flow as soon as possible to, among others, get rid of donors. A number of issues/contestations arising in relationships among various

7 Indian Ocean Newsletter, nº1350, 15 February 2013.

8 The DRC has produced oil since the 1970s in the Bas-Congo province. Partly located offshore, the fields are operated since 2004 by the French firm Perenco and currently producing 25000 bpd.

9 Kulhubuze Zuma, the nephew of the current South African president, is the only one to have officially backed the two firms.

10 The Israeli mines tycoon Dan Gertler is also very often quoted. 
stakeholders and legislative processes and technicalities have been a hindrance and have delayed the process.

\section{Burundi, Rwanda and Tanzania exploration}

Also located in a Grabenic zone where hydrocarbons are easily trapped as was previously shown around the Lake Albert, two other lakes in the Great Lakes region are coveted by companies: Lake Kivu and Lake Tanganyika. In-between Rwanda and DRC, Lake Kivu has very important reserves of methane in its water depth. This gas is already used by Rwanda to supply a small pilot project called KP One (1 MW) sponsored by Kigali's government (and in the past by World Bank). In the second half of 2013, an American company Contour Global is supposed to commission the first phase of a $100 \mathrm{MW}$ project supplied by this reserve in methane. When completed, this plant called "Kivuwatt" will double Rwanda's power capacity of and might even enable the country to export electricity. As observed earlier in the Lake Albert case, the DRC side of Lake Kivu is not as advanced; no concessions are allocated yet. The Belgium cooperation plans to finance bathymetry studies in 2013 to help demarcate coherent blocks on the Congolese side of the lake ${ }^{11}$. Rwanda might be the first to supply electricity to the growing town of Goma (North Kivu's capital), adjacent to the Rwandese city of Gisenyi. Oil exploration in Rwanda is at its very early stages, even though a Canadian company named Vanoil recently got an exploration contract around Lake Kivu and might conduct a seismic study in 2013. The potential size of oil reserves in Rwanda is totally unknown at this stage.

The other very promising area in the great lakes region is the Tanganyika Lake divided between four different sovereignties (DRC, Burundi, Tanzania and Zambia). In the North, Burundi has allocated two blocks to the British firm Surestream chaired until 2012 by Moustapha Niasse (head of the parliament and former Prime Minister of Senegal) and one to the Nigerian firm AZ Petroleum. On the Tanzanian side, Tanganyika South has been explored since 2008 by the Australian Beach Petroleum whereas Tanganyika North was won by Total in $2011^{12}$. Neither DRC nor Zambia have allocated blocks around the Lake. In the Zambian case, it seems the southern part of Lake Tanganyika is not that interesting from a geological perspective. As for DRC, 10 blocks were demarcated but have never been officially offered. Burundi and Tanzania are in the seismic study phase. The lake, 1433 meters deep, the second deepest in the world (after Lake Baikal), will be hard to drill because of deep offshore conditions. In addition, it is landlocked. Oil companies are still studying how to cope with these numerous challenges before entering any drilling phase.

11 Africa Energy Intelligence, n696, 26 March 2013.

12 This block has been once more offered to potential investors in a bid which might take place in October 2013, according to the national Tanzanian firm of oil TPDC. 


\section{South Sudan, Kenya, Ethiopia and Somalia hydrocarbons exploration}

It would be a mistake to discuss oil in "Median Africa" without remembering that oil production in the region historically began in 1999 in the southern part of Sudan, which became Independent and formed South Sudan on the $9^{\text {th }}$ July 2011. This partition happened after two very long civil wars between Khartoum and different rebellions in the South (two civil wars since 1955). After the Comprehensive Peace Agreement (CPA) of 2005, the two parties decided to experiment a joint government in Khartoum and to set up a referendum in 2011 for independence where $98 \%$ of south Sudanese inhabitants voted for a complete separation. Thanks to Chinese, Indian and Malaysian investors, Sudan managed to reach 470000 bpd up to 2012 when litigations between the North and South led to a shutdown. Oil production might start again in the South in 2013 but this sector will remain under threat as long as Juba will have to deal with its worst enemy to export oil. All the infrastructures lead to Port Sudan, and the southerners feel trapped by their geography. Very little oil exploration in South Sudan took place outside the current oil producing blocks. Hopes are high about the huge block B $\left(118000 \mathrm{~km}^{2}\right)$ operated since the 80 s by Total. It might be divided in several smaller blocks where American major Exxon, Kuwaiti Kufpec, and South African firms might enter ${ }^{13}$. To date, no clear strategy was announced by Juba's ministry of oil in regard of block B division. Yet new rounds of bids are planned in 2013/2014 and new blocks are to be defined.

Kenya is the next "big thing" according to geologists. Even if we are at an early stage, the wells drilled by Tullow around Lake Turkana in the northern region (Anza Basin) of the country are very promising. Tullow also has interests in the Omo region of Ethiopia, a northern extension of the Lake Turkana zone. Drilling was planned in 2012 to see whether the oil field spreads north. On the Kenyan coast, blocks operated by Total were drilled offshore, in the late 2012. Results will determine the way forward. Apart from its intrinsic geological qualities, Kenya's location might turn the country into a regional oil hub to export South Sudan and Ugandan oil, as we shall see later.

Somalia is also potentially an important player in the region. The country is currently divided into three zones: Somaliland (Hargeisa), Puntland (Garowe) and Somalia (Mogadishu). Since the fall of Siad Barré in 1991, blocks that were explored in the country at the time by Marathon, Chevron or Shell were frozen and put under "force majeure". With the election of Hassan Cheikh Mohamud as President of Somalia in 2012 and the government recently put in place, advisers of the current natural resources minister Abdirisak Omar Mohamed are working to foster new exploration from the companies under "force majeure" and to attract new firms offshore and onshore. Ever since the 90s, Somaliland and Puntland have stopped waiting for a signal from Mogadishu. Licenses were given out by the government of Somaliland to well-established companies such as Ophir, Genel (or DNO in April 2013) that conducted seismic campaigns. In Puntland, several

13 Africa Energy Intelligence, nº95, 19 March 2013. 
small companies from Australia are exploring the blocks of Nugaal and Dharoor. In 2012, two wells were drilled by the Canadian based company Africa Oil Corp. No oil was found but exploration is still ongoing, triggered by the oil and gas reserves found in Yemen, where geology has similarities with Puntland and Somaliland. Mogadishu is trying to show its muscles and extend its power to the internationally unrecognized zones of Puntland and Somaliland with the aim of controlling oil exploration over all Siad Barre's Somalia. Interviews with ministers and executives from the ministries of these zones and of the new government of Somalia showed that no country was ready to abandon its prerogatives and that the sovereignty issue is still extremely critical. Somaliland and Puntland who have more effective parliaments and governments than Somalia ${ }^{14}$, and who in a way are able to "deliver", feel they have nothing to gain from leaving oil and mines to be handled by Mogadishu where instability is still critical. Overlapping interests need to be carefully handled and overseen by the international community currently supporting Hassan Cheikh Mohamud.

\section{Tanzania and Mozambique gas}

Even though this paper is centered on the Great Lakes region, oil and gas interests extend to the Ruvuma basin on the border between Mozambique and Tanzania with gas discoveries since 2010. BG and Statoil managed to find 30 trillion cubic feet of gas in Tanzania while ENI and Anadarko discovered more than 100 trillion cubic feet of gas in Mozambique. For the sake of comparison, the entire reserves in the two countries represent approximately what Nigeria found in 60 years (180 TCF). Tanzania and Mozambique are going to be a major world-class gas province in a position to supply Asia around 2018/2020. The existing reserves will allow a regular supply for several decades. The Tanzania and Mozambique ${ }^{15}$ economies will very soon be driven mainly by the gas sector, creating dominant revenue from hydrocarbons in the national income with expected drawbacks. Oil will also become a major sector in Uganda's economy; but due to the number of inhabitants (around 33 million), reserves of 3.5 billion will have less impact per capita (even if they well managed by the central government), compared to Mozambique and the ratio of 100 trillion cubic feet of gas for 24 million people. Mozambique and Tanzania are on the way to becoming the regional hub for gas exportation in the Indian Ocean.

14 Somaliland might be considered as a totally independent country with its own government since the 1990s. 15 Both countries are producing a little gas since 2004. For Tanzania, the gas produced in Songo Songo Island is transported through pipelines to Dar es Salaam to supply the Ubongo power plant (180 MW). In the case of Mozambique, the South African firm Sasol is handling the fields of Pande and Temane to supply one of their plants of Secunda in the Mpumalanga province which produces synthetic fuel. 


\section{Geopolitical issues at stake with oil and gas in Median Africa}

\section{Border issues}

As stated in the introduction, oil development in eastern Africa raises specific issues which were generally not found in Western Africa. Border litigations represent the first issue. In this respect, Lake Albert first drew attention in August 2007 when an engineer from Heritage Oil was killed by Congolese soldiers while conducting a seismic survey close to the island of Rukwanzi in the southern part of the lake. Heritage Oil argued they were on Uganda's side of the border when this happened while the Congolese soldiers -who had summoned the boat occupants a couple of hours before the shoot-out- explained the survey was conducted in Congolese territory. This specific dynamic in border conflicts has implications for state sovereignty. The cherished principle by nation states becomes even more important where oil is speculated or deposits are confirmed at the disputed border. No wonder that overzealous nationals and state agents can kill, to protect first sovereignty and next an anticipated economic yield from the oil. As a result of the above incidents at the border, two bilateral agreements between DRC and Uganda (Ngurdoto in 2007 and Dar es Salaam in 2008) were signed to prevent other similar conflicts. The island of Rukwanzi is now jointly administered by the two countries and litigation on the border demarcation is or the time being frozen with an explicit ban on exploring oil in a strip of five kilometers along the two sides of the former colonial border.

The violent Rukwanzi incident showed the potentially dangerous choice of landmarks made by colonial powers to demarcate borders. In 1915, Great Britain and Belgium decided to take the Semliki riverbed south of Lake Albert as the border starting point $^{16}$. But just as any river, the Semiliki was shifting its course. The river has moved a hundred of meters in a century and the two Independent countries cannot easily agree on which limit to choose today (the 1915 treaty status would lead to a largely disadvantage DRC). A lasting solution has not been reached yet, though a bilateral commission has worked on it $^{17}$. In the region, colonial borders, are still found to be ground for conflict like for instance between the two Sudan where oil is concentrated. There is also a border problem on Lake Malawi between Tanzania and Malawi. We can't foresee yet whether the same might occur on Lake Tanganyika or Lake Kivu as exploration is still at an early stage. Borders can remain stable for decades like in the Lake Albert region in the past even though they were badly defined, yet when oil is found, border issues flare up easily.

Apart from being vague and based on shifting natural landmarks, the border issue between DRC/Uganda on Lake Albert was plagued by a very complicated bilateral relationship ever since the first Congolese war of 1996/1997. Many similar cases were handled in a peaceful manner for instance along the border between Tunisia and Libya, or Senegal and

16 Augé, B. Hydrocarbons Tied with Border Conflicts in the Great Lakes Region of Africa, Governance of Oil in Africa, Unfinished Business, Institut Français des Relations Internationales (IFRI), Paris, La documentation française, 2009, pp. 165-193. 17 Benjamin, Ibid. 
Bissau Guinea, or Nigeria and Sao Tomé \& Principe. But in this case the difference is that Uganda and Congo did not have much interaction before trying to solve the border issue tied to oil exploration. Moreover, in the case of Uganda, oil had already been found whereas in all the cases previously quoted, exploration was still at an early phase. After a first Congolese war where Uganda and Rwanda fought next to Laurent Désiré Kabila to take over power in Kinshasa from the hands of Mobuto Sese Seko (1996/1997), the second Congolese war (1998-2003) led by Laurent Désiré Kabila (1997-2001) and then his son Joseph Kabila (since 2001) was fought against Ugandan and Rwandan armies and proxies. After this war, other rebellions were allegedly supported by Uganda and Rwanda like the CNDP (Congrés national pour la defense du people) of Laurent Nkunda and even more recently the M23 of Bosco Ntaganda (now facing the international court in The Hague). This turbulent recent history has nourished deep suspicions between neighbors. It contributed to create border problems and led to the August 2007 murder. A cable leaked in 2010 by Wikileaks highlighted that presidents Kabila and Museveni were getting along well but that the Congolese population which has endured years of conflict (and still does), in which Uganda and its proxies play a role, is encountering difficulties to recover from this endless insecurity ${ }^{18}$.

Apart from Lake Albert, similar border conflicts and litigations might occur in the Lake Kivu and Lake Tanganyika regions between DRC and its neighbors. The biggest fear concerns Lake Kivu, where massive distrust and suspicion exist between civil servants in the ministry of hydrocarbons in Kinshasa and their counterparts in Kigali, as well between the armies. The alleged "stealing" of gas by Rwanda could always be used by DRC politicians as a motive for conflict between the two countries. Conflict doesn't necessarily mean war; it might also lead to tension and escalation of words with consequences on the ground such as anger towards specific communities. In the case of Lake Tanganyika, tensions might not flare up as violently as Tanzania remains a main actor for peace in the region; Benjamin Mkapa and Jakaya Kikwete have persistently played the role of mediators in the great lakes region ever since the first Congolese war. This of course doesn't imply that oil exploration will remain peaceful; it might also bring up suspicion between politicians and civil servants in charge of oil from both sides.

\section{Market and transport}

Based on current knowledge in the geology of the region and thanks to exploration campaigns, only one zone in Eastern Africa has potentially enough oil for organized production: the Ugandan side of Lake Albert. Kenya and Ethiopia are still at an early stage of exploration, as well as Burundi and Rwanda. Uganda is facing the same dilemma for oil as Tanzania and Mozambique are facing for gas about the splitting of the resource between local needs and exportation. The already known reserves around Lake Albert allow oil companies executives to forecast a "plateau production" around 250 000/300 000 bpd (for at least two decades). By mid-April 2013, the Ugandan president, Yoweri Museveni, had

18 Augé, B. Produire du pétrole en zone de conflit: Cas de l'Afrique médiane, PhD Diss., Paris 8 University, 2012, p. 277. 
managed to convince oil firms to make 30000 bpd of crude available for a refinery that would be built in the eastern district of Hoima ${ }^{19}$. Tullow, Total and CNOOC fought a fierce battle against Museveni who was originally, demanding a regional refinery of 150000 to 200000 bpd. Museveni was finally convinced that a regional plant would not be profitable for investors due to the competition of the Mombasa plant ${ }^{20}$. Still he insisted the Hoima plant will later expand to $60,000 \mathrm{bpd}$ to meet with local consumption increase. Uganda now has to seek for funds for the plant and investors willing to operate it (the Russian and Chinese are already on the list). Oil companies and governments also have to agree on another sensitive issue: which route for the exportation pipeline? There are three different routes studied since 2010: Mombasa, Lamu and Dar es Salaam. The easiest way is definitely Mombasa, an oil pipeline already exists from Mombasa to Eldoret - and plans for its extension to Kisumu are already under way - and supplies refined products to Kenya and Uganda by road from Eldoret. In the event that Mombasa is chosen as the export port, a new pipeline would be built from Hoima to Eldoret and then would double the current one to reach Mombasa where necessary infrastructures are already in place. This choice is evaluated at around 3.5 billion dollars by Tota ${ }^{21}$. A dual way carriage pipeline, meant to bring petroleum products and to send crude oil, is already in its bidding phase in the Ministry for Energy in Kampala ${ }^{22}$. The second route under study would lead to Lamu in Kenya (close to the Somali border). This would be an expensive decision as there is almost no infrastructure constructed yet in $\mathrm{Lamu}^{23}$. In addition, land acquisitions for the entire 1490 kilometers pipeline will need to be negotiated ${ }^{24}$, whereas for Mombasa, half the way is already covered by the other petroleum products pipeline. In spite of this, Total foresees that this choice would cost less than the Mombasa route: only 3 billion dollars. Initial work has begun in Lamu in 2012, yet up to now, no funds are available for a deep port and an oil terminal (Qatar planned to invest in 2007, but nothing came out of the plan). The last choice, by far the longest (more than 1600 kilometers) and also the most expensive, about 4 billion dollars, is Dar es Salaam. The final decision will be made in 2013.

There are constellations of issues that arise in choices of the market for oil, whether or not to market refined or crude oil, and the mode of transport for the product. The discussions haggle over these issues among the stakeholders is a reassertion of specific leverages on each part; to ensure that the resulting option produces more benefit to them. ${ }^{25}$ Such capitalist motivated assertions of positions will always be of currency in the oil sector in "Median Africa", with relatively poor and land-locked countries struggling to strategically position

19 Africa Energy Intelligence, nº97, 16 April 2013. Daily Monitor, 16 April 2013.

20 Currently the Mombasa refinery, in a position to refine half the needs of Kenya, is in financial trouble and operating at half capacity. The building of a new refinery is planned. The East African, 4-10 May 2013, p. 4.

21 All figures of pipelines cost can be found in Africa Energy Intelligence, nº96, 02 April 2013.

22 As indicated in discussions with civil servants of the Ministry, March 2013.

23 Coloma, T. «En attendant le port qui doit sauver le Kenya », Le Monde Diplomatique, April 2013.

24 Augé, B. Produire du pétrole..., op.cit.

25 Uganda believes that having a refinery at home will mean saving on transport costs, fetching more from oil, and also be in position to use the by-products from the refining processes. 
themselves to benefit from the finite resource. On the other hand are found profit-motivated companies, with a similar agenda.

\section{Oil Governance in Eastern Africa and Uganda}

In Eastern Africa, oil governance represents a real challenge. In 2012, five western bilateral donors stopped their financial aid after the office of the Prime Minister mismanaged 13 million dollars ${ }^{26}$ which were channeled for reconstruction programs in the previously war-torn northern Uganda. Investing massively in oil, gas and mining industries in a country with limited financial grounding and past expertise in the extractive sector is a risky endeavor which creates new governance issues. When high democratic standards are not in place before these sectors become dominant in the economy, there is likelihood that massive investments in mining would worsen the fragile political and economic situation of the country. No improvement in governance was noted thanks to oil sector in Equatorial Guinea, Sudan, Chad and Niger recently. But in the case of Ghana, where oil production started in 2010, some hope remains thanks to high democratic standards (two strong parties alternating in power since 1992) which enabled debates on how to manage the sector, and how to channel the money to avoid corrupt practices.

In Uganda, the next country in line for oil production in Eastern Africa, there are more and more concerns about the political, financial, economic, social and environmental situation, and also management of expectations. Government's official dream as seen in the National Oil and Gas Policy for Uganda 2008 is to manage the finite resource to contribute to society by eradicating poverty. Corruption scandals that have mired the oil sector and high levels of secrecy are indicative of self-interests; garner as much as possible from the sector for self. Yet, the high expectations of people in the region, the country's smaller centers of power/ political/administrative units such as districts and cultural institutions, seeking to claim a stake of entitlement to the revenues from the sector, have not been well managed. The hallmark of this is a lack of consensus at the country level, and revealing sign that consensus at a wider regional level with even more social and political stakeholders with diverse interests on these issues could be mythical.

One of the main issues to tackle is the financial and speculative dimension of oil development and link to corruption found at all levels, from speculative transactions in oil contracts to land-grabbing, speculative land deals, creation and transfer of titles. For instance, in Uganda just as in DRC, powerful stakeholders in government started by making money from contracts ${ }^{27}$. The State reacted by making efforts to gain from taxes, yet having to face the financial cost of a legal battle (high cost of court case with Heritage), Tullow has agreed to pay the government and in turn is suing Heritage.

26 The Independent, 26 October-01 November 2012, p. 10-12.

27 For instance, see the case of Heritage - linked to the President's half brother - selling to Tullow. http://www.ide. go.jp/English/Data/Africa_file/Company/uganda01.html. 
The legal and policy framework in Uganda thus far is not strong enough to unseat the political and other 'imperatives' of government and other key players in the sector. In a sector of this nature, transparency, accountability and public empowerment to take part in decisions are among the legion key issues of governance. ${ }^{28}$ The public needs information, in order to demand for accountability. The legal framework, say the Constitution of Uganda 1995, article 41 (1) and Access to Information Act ${ }^{29}$ section 5, stipulates it is everyone's right to seek information from the state or any of its organs; unless the security of the state will be prejudiced or someone's privacy is likely to be interfered with. This right is also catered for within the spectrum of environmental protection. ${ }^{30}$ The Petroleum (Exploration and Production) Act ${ }^{31}$ section 59 to some extent contradicts the preceding laws. According to that section, with a few exceptions in clause 2 , information furnished by a licensee cannot be disclosed without consent of the licensee except to a Government Minister or an officer in the public service. It was on the basis of some of the above that information in the Production Sharing Agreements (PSA) was kept top secret from the public until intense pressure from Parliament. Institutions such as Parliament and Civil Society Organizations like Advocates Coalition for Development (ACODE) have had principle-driven fights in the oil processes of legislation in Uganda, in the public's interest. The highly politicised parliamentary debates on oil in October 2011 have clearly shown that the President was keeping the sector under close control. None of the demands formulated by opposition MPs were taken into account in the Petroleum (Exploration, Development and Production) $\mathrm{Bill}^{32}$. The invisible arm of political control over processes in the oil sector is seen in some incidents, such as the case of Twinobusingye Severino v. Attorney General ${ }^{33}$, in which an advocate from Hon. Amama Mbazizi's constituency successfully challenged a resolution of Parliament setting up an ad hoc Committee to, among others, investigate bribery claims and requiring the concerned ministers: Hon. Amama Mbabazi (Prime Minister of Uganda), Hon Sam K. Kutesa (Minister of Foreign Affairs), and Hon Hillary Onek (Minister of Internal Affairs) to "step aside" from their offices in the interim. This case filed by Twinobusingye, also an NRM supporter, ended with an award of a hefty and contested sum of 2.9 Billion Uganda shillings in costs from government ${ }^{34}$ The contestations sent shivers into the National Resistance Movement (NRM), Museveni's party, where out-spoken and critical leaders, such as Theodore Ssekikubo who led the debates in parliament, were finally expelled from the party. ${ }^{35}$ Advocates Coalition for Development (ACODE) were among the civil society organizations fighting against the licensing powers given to the Minister under the Petroleum (Exploration, Development and Production) Bill. In disregard of their role, former Energy Minister Hillary Onek was always emphatic that NGOs had no business with oil but only with taking care of orphans; they needed permission by the

\footnotetext{
28 See Oloka Onyango, J. et al. "How Much Do We Really Know? Decentralization, Access to Information and Improving Accountability in Uganda”, Human Rights and Peace Center, Working paper, no. 28, June 2010.

29 No. 6 of 2005, came into force on $20^{\text {th }}$ April 2006.

30 National Environmental Act Cap. 153, 200 Laws of Uganda, section 86.

31 Chapter 150 Laws of Uganda.

32 Now the Petroleum (Exploration, Development and Production) Act 2013, that commenced on April $5^{\text {th }}, 2013$, repealing the Petroleum (Exploration and Production) Act, Cap 150.

33 Constitutional Petition No.47 of 2011.

34 See "Shs 13 Billion costs would be crazy", Observer (Editorial) February 27, 2013, p.8.

35 Daily Monitor, $16^{\text {th }}$ April 2013, p.4, 5.
} 
Ministry to engage in any research or work in the oil region about oil. ${ }^{36}$ Following its sponsorship of a workshop for Parliamentarians on the oil laws, ACODE was warned by the president, promised deregistration and Bank of Uganda ordered for a record of all its accounts. ${ }^{37}$ Suffocation of the civil society that normally speaks for the public leaves only the government and its self-seeking individuals in charge. The nomination, in 2011, of Irene Muloni (a specialist of electricity) as the Cabinet Minister for Energy and Minerals is also worrisome. She has no clear vision of how to manage the oil sector. Oil matters are mainly driven by the Permanent Secretary of the ministry of Oil and Minerals, Kaliisa Kabagambe, who has worked in the ministry since in the late 70s and Ernst Rubondo, the commissioner of Petroleum Exploraiton and Production Department (PEPD) based in Entebbe. Kaliisa has a direct relationship with Museveni which points at the personal involvement of the president in decisions regarding the oil sector which bypasses existing institutional frameworks, showing the wrong signal for the future management of the oil revenue. There is a clear personalization of the regime and presidentialization of the oil sector in Uganda.

The prospective view on the environmental and ecological management of the oil exploitation is not impressive, taking into account that one of the main areas of future production is located in Murchison Falls Park, a Ramsar site, recognized internationally for its importance and value. The investment $\mathrm{Code} \mathrm{Ac}^{38} 92$ requires that an investment for which a license is issued should not be a danger to the environment or the ecology. The National Environment Management Authority (NEMA), as the central body in charge of environment licensed companies, to look into the management of oil waste; those mandated include CNOOC Uganda limited, Epsilon and Hariss International. ${ }^{39}$ The oil companies have not procured the services of these companies to treat their wastes, at the time of writing. There have been media reports on the failure of oil companies to treat the waste from their activities so far. Lots of mud cuttings are at the moment in open spaces and heaps on the ground, only covered with polythene, and liquid waste in open concrete pits without any kind of treatment. If the situation is precarious before the oil drilling starts, it is unrealistic to hope for better after it has started. In the absence of imminent compulsion from laws or policies to do good and the fact that imperative of Corporate Social Responsibility is not yet deeply rooted, the communities are at a risk of consequences of environmental degradation from oil activities.

Also, the Albertine region of Uganda is experiencing an increasing number of contestations on land; the powerful displacing the poor with little or no compensation, disputes between and among the poor over land. ${ }^{40}$ This is against the backdrop that land governance in Uganda, in the recent times characterised by disregard of institutions provided for by law to handle such disputes in favor of political options. An example is the

36 Matsiko, H. “ACODE under Investigation”, The Independent, April 06-09 2012.

37 Matsko, Ibid.

38 Chapter 92 Laws of Uganda, section 18 (2) (d).

39 Daily Monitor, 16 April 2013, p. 6.

40 See Musiime, C. The Great Land Rush, OIL in Uganda, August 2012, Issue 2 and 3 (Note that this issue contains more articles on land wrangles in the region). 
appointment of a Committee headed by junior State Minister for lands; Aida Nantaba, to decide disputes over land; in many occurrences operating outside of the law. ${ }^{41}$

So many issues have arisen in the oil sector in Uganda so far, but a paucity of success stories in the legal, policy and other frameworks intended to address them. Rather, power has developed in a way to lend credence to politically motivated and self-interested discourses of individuals; over those of the public. This does not provide a strong (but only a shaky) ground, upon which regional initiatives can be constructed. Instead it presents more skeletons that could haunt optimistic speculation for the future of oil in the great lakes region.

On the other side of the border, in DRC, the minister of hydrocarbons has no power at all, all decisions, which are rare, are taken by advisers of the president (the most influential ones are not always the ones officially appointed). The main difference between DRC and Uganda is that Yoweri Museveni is able to enforce decisions he takes and that the link with the Permanent secretary is very efficient as long as there is no difference of view with the oil companies. On the contrary, there are numerous actors in the DRC who are working against each other: appointed advisers against informal advisers in the presidency, the minister against civil servants in the ministry, the national oil corporation, Cohydro, against all the other bodies. The disorganization of the oil sector in DRC is also reflected in the never ending process of rebuilding a nation in which state institutions are not meant to serve the interests of private individuals but serve the wider interests of a nation.

In the case of the other previously mentioned countries in the region, it is not easy to give a prospective analysis, as we are still at an early exploration phase. The activities are not yet considered as the "golden sector to capture for Presidents and regimes" since reserves need yet to be confirmed. In Kenya, the choice of the Minister for Energy by the newly elected leaders Uhuru Kenyatta and William Ruto is revealing. Davis Chirchir, the secretary-general of the United Republican Party (URP) of William Ruto and the architect of the alliance between the URP and Kenyatta's The National Alliance (TNA) was chosen, late April 2013. This constitutes a political appointment ${ }^{42}$. Kenyatta favored a close ally of his Vice-president to a specialist of the oil sector. In Tanzania, in May 2012, in a move which was viewed positively, president Kikwete decided to appoint a geologist, Sospeter Muhongo, previously a professor at the University of Dar es Salaam, as Minister for energy and minerals. In turn, the Professor chose an experienced geologist, Sosthenes Massola, as his closest adviser. The previous Minister for Energy, William Ngeleja, was an experienced politician with no specific knowledge about the sector. Conversant with oil issues, the new minister has no electoral constituency to cater for. Until now, Professor Muhongo is working on a gas master plan. Yet, it is still too early to see the outcome of these two contrasting decisions in Kenya and Tanzania.

41 See "President Museveni Freezes State House Land Unit Activities," available at http://newsuganda.ug/news/ latest/uganda-news-picks/president-museveni-freezes-state-house-land-unit-activities/56q1.91337, accessed May 27, 2013.

42 Africa Energy Intelligence, nº98, 30 March 2013. 
Awareness of issues at stake in the development of an oil sector requires technical knowledge. Yet conflicting interests are arising and need political solutions and mediation skills. Legal frameworks are in place or are still to be worked out, but without political goodwill and the strengthening of governing institutions, a departure from personal power, they will remain ineffective.

\section{Conclusion}

This paper aimed at giving a brief overview of the oil exploration and production (in the Eastern and Great Lakes region of Africa) where each country has its own trajectory. Ever since 2006 and the first discoveries, Uganda set the pace and now the entire region has become a hotspot for oil exploration. More reserves are yet to be found in the Kenyan and Ethiopian region of Lake Turkana and offshore along the coast of Kenya, Tanzania and Mozambique. This new industry might be a blessing or a curse for Uganda. The planned growth of the national GDP might suffer a setback with organized thieving. Several challenges need to be addressed in Uganda. The major one has to do with the financial implications of the oil development, the need for investments but also the need to tame high expectations, speculation and corrupt deals. The second one deals with the low level of technical expertise in oil. The third concerns the environment and its protection, with communities depending on fish, agriculture and livestock for livelihoods in areas concerned by oil production and also the importance of the area of Murchison Park as a biodiversity hotspot.

From a governance perspective, there is an institutional vacuum and a need to create specific bodies to handle the sector: regulatory bodies, state oil companies and a strong and independent ministry of oil and energy. These bodies need a degree of autonomy and highly skilled civil servants, a difficult target to attain especially when oil and potential wealth attract interest from all starting from the top. Generally, presidents get personally involved in oil decisions. Moreover, to be efficient and able to make proper decisions, people in government, need adequate training and exposure. Parliament for instance has an important role to play in regulating the oil sector. Norway is closely involved in such trainings in Uganda as in many other African countries. Norway has been successful in making these trainings available upon request from African states and not, as in the case of the World Bank, as a condition to get access to soft loans. Yet considering the political landscape and direct interest of the powerful in the oil sector, knowledge of the players might (by itself) be insufficient to slough off pressure to support strategic positions of the powerful in oil management.

Eastern Africa is plagued by border litigations and shared oil or gas reserves might create new ones in the near future. Yet, through economic interdependency, shared oil and gas reserves might also start a new era of cooperation. The episode of Lake Albert in 2007 between DRC and Uganda forced the two "enemies" to talk on borders but also on many other subjects during the Ngurdoto and Dar es Salaam treaties. These talks have 
drastically lowered the suspicion between high-ranking civil servants and also pushed for better coordination between the two armies. In the future, when DRC finds oil on its side of the Lake, exports are likely to go through Ugandan territory. In contrast, levels of distrust remain high between DRC and Rwanda, over the control of methane in Lake Kivu and this does not speak well about the future. Currently, endless discussions in Kampala on the M23 crisis seem to give more credibility to a lasting conflict between the two enemies of the 1998/2003 war. When shared between several countries, Management of oil resources might be used as a barometer to measure existing ties and relationships and their vulnerability. Due to the geography and to the history of conflicts, as well as individual state trajectories, the regional management of oil resources and infrastructures is especially challenging.

\section{Bibliography}

Augé, Benjamin. 2009, Hydrocarbons Tied With Border Conflicts in the Great Lakes Region of Africa, Governance of Oil in Africa, Unfinished Business, Institut Français des Relations Internationales, La documentation Française, Paris, pp. 165-193.

Augé, Benjamin. 2012, Produire du pétrole en zone de conflit: Cas de l'Afrique médiane, PhD Diss., Paris 8 University, Paris.

Collier, Paul. War Guns and Votes: Democracy in Dangerous Places, Harper Collin Publishers, 2009.

International Crisis Group (ICG). 2012, Black Gold in the Congo: Threat to Stability or Development Opportunity? July 2012.

Global Witness. 2012, Uganda's Petroleum Legislation. Safeguarding the Sector, March.

Kashambuzi, Reuben. 2010, The Story of Petroleum Exploration in Uganda (1984-2008), Kampala, Impro Publications Ltd.

Lacoste, Yves. 1997, "Introduction », Hérodote, numéro spécial 'Géopolitique d'une Afrique médiane', nº86-87.

Oloka Onyango J. et al., 2010, "How Much Do We Really Know? Decentralization, Access to Information and Improving Accountability in Uganda", Human Rights and Peace Center Working paper No. 28, June, 2010.

\section{Press and internet sources}

Africa Energy Intelligence, $\mathrm{n}^{\circ}$ 656, 20 July 2011.

Africa Energy Intelligence, n696, 26 March 2013, 02 April 2013.

Africa Energy Intelligence, n695, 19 March 2013.

Africa Energy Intelligence, n697, 16 April 2013. 
Africa Energy Intelligence, $\mathrm{n}^{\circ}$ 698, 30 March 2013.

The Daily Monitor, 16 April 2013. Agencies, "Oil waste piles as firms delay disposal", p. 6. The Daily Monitor, 16 April 2013. Mugerwa Yasin, "Repeat of history as NRM expels 'rebel' MPs", p. 4, 5.

The Daily Monitor, 16 April 2013. Ahimbisibwe Patience, "Government agrees on refinery", p. 1, p. 3.

The East African, 20-26 April 2013. Abdallah Halima, "Challenges ahead for Uganda's pipeline refinery", p. 6.

The East African, 4-10 May 2013. Senelwa Kennedy, "Oil crisis looming as marketers opt out of refinery", p. 4.

Indian Ocean Newsletter, ${ }^{\circ} 1350,15$ February 2013.

Le Monde Diplomatique, April 2013. Tristan Coloma, "En attendant le port qui doit sauver le Kenya", p. 12-13.

The Independent, 26 October 26-01 November 2012. Nyanzi Peter, "Auditor General names government's money swindlers", p. 10-12.

The Independent, 06-09 April 2012. Matsiko Haggai, “ACODE under investigation”, p. 21. The Observer, 27 February 2013. Editorial, "Shs. 13 Billion costs would be crazy”, p. 8.

OIL in Uganda, August 2012, Issue 2 and 3. Musiime Chris, "The Great Land Rush".

"President Museveni Freezes State House Land Unit Activities", available at http://newsuganda.ug/news/latest/uganda-news-picks/president-museveni-freezes-state-house-landunit-activities/56q1.91337. Accessed 27 May 2013.

"Benefits offered and relations with government", available at http://www.ide.go.jp/English/Data/Africa_file/Company/uganda01.html, accessed 25 May 2013.

\section{Laws}

Access to Information Act No. 6 of 2005 (came into force $20^{\text {th }}$ April 2006), section 5.The Investment Code Act, Chapter 92 Laws of Uganda, section 18 (2) (d).

The Constitution of Uganda 1995, article 41 (1)

National Environmental Act Chapter 153, Laws of Uganda, section 86.

The Petroleum (Exploration and Production) Act, Chapter 150 Laws of Uganda, section 59.

Petroleum (Exploration, Development and Production) Act 2013.

\section{Case(s)}

Twinobusingye Severino v. Attorney General Constitutional Petition No.47 of 2011. 